\title{
Bioconversion of Biodiesel-derived Crude Glycerol to 1,3-Dihydroxyacetone by a Potential Acetic Acid Bacteria
}

\author{
(Biopenukaran Gliserol Mentah Janaan Biodiesel kepada 1,3-Dihidroksiaseton oleh Potensi Bakteria Asid Asetik)
}

\author{
VARAVUt TANAMOOL, PiYOROT HONGSACHART \& Wichai SOEMPHOL*
}

\begin{abstract}
Acetic acid bacteria $(A A B)$ isolated from natural resources and fermented plant beverages were screened to produce 1,3-dihydroxyacetone (DHA) from non-detoxified crude glycerol. Among them, the isolate NKC115 was identified as Gluconobacter frateurii and produced the highest amounts of DHA. Subsequently, the effects of growth-medium conditions (initial $\mathrm{pH}$, crude glycerol concentration and nitrogen sources) on growth and DHA-production capability were examined. The results showed that the crude glycerol concentration increase to above $100 \mathrm{~g} / \mathrm{L}$ suppressed growth and DHA production. The highest amount of DHA obtained was $27.50 \mathrm{~g} / \mathrm{L}$, from an initial crude glycerol concentration of $100 \mathrm{~g} / \mathrm{L}$. Meanwhile, an initial pH of 5.5-7.5 in the YPGc medium did not significantly affect the bacterial growth and DHA production. The optimal nitrogen source was peptone, with DHA production at $34.70 \mathrm{~g} / \mathrm{L}$. Furthermore, overexpression of the nhaK2 gene encoding for the $\mathrm{Na}^{+}\left(\mathrm{K}^{+}\right) / \mathrm{H}^{+}$antiporter from Acetobactor tropicalis SKU1100 in G. frateurii NKC115 improved growth and increased the accumulation of DHA $(37.25 \mathrm{~g} / \mathrm{L})$ from an initial crude glycerol concentration of $20 \%$. These results indicated that the expression of this antiporter might maintain an optimal intracellular $\mathrm{pH}$ and concentration of $\mathrm{Na}^{+}$or $K^{+}$, leading to the cells' ability to tolerate high concentrations of crude glycerol.
\end{abstract}

Keywords: Acetic acid bacteria; biodiesel; crude glycerol; dihydroxyacetone

ABSTRAK

Bakteria asid asetik (AAB) yang dipencilkan daripada sumber alam dan minuman fermentasi berasaskan tumbuhan telah ditapis untuk menghasilkan 1,3-dihidroksiaseton (DHA) daripada gliserol mentah yang belum disingkirkan toksiknya. Antara mereka, pencilan NKC115 telah dikenal pasti sebagai Gluconobacter frateurii dan menghasilkan jumlah DHA yang tertinggi. Seterusnya, kesan keadaan medium pertumbuhan ( $\mathrm{pH}$ pemula, kepekatan gliserol mentah dan sumber nitrogen) terhadap pertumbuhan dan kemampuan penghasilan DHA telah dikaji. Keputusan menunjukkan kepekatan gliserol mentah bertambah melebihi $100 \mathrm{~g} /$ L pertumbuhan kawalan dan penghasilan DHA. Jumlah DHA tertinggi diperoleh adalah $27.50 \mathrm{~g} / \mathrm{L}$, daripada kepekatan gliserol mentah $100 \mathrm{~g} / \mathrm{L}$. Sementara itu, pH pemula 5.5-7.5 di dalam medium YPGc tidak mempengaruhi pertumbuhan bakteria dan penghasilan DHA dengan nyata. Sumber optimum nitrogen ialah pepton dengan penghasilan DHA pada $34.70 \mathrm{~g} / \mathrm{L}$. Tambahan pula, expresi melampau daripada gen pengekodan nhaK2 untuk antipengangkat $\mathrm{Na}^{+}\left(\mathrm{K}^{+}\right) / \mathrm{H}^{+}$daripada Acetobactor tropicalis SKU1100 dalam G. frateurii NKC115 memperbaiki pertumbuhan dan meningkatkan pengumpulan DHA $(37.25 \mathrm{~g} / \mathrm{L})$ daripada kepekatan gliserol mentah pemula sebanyak 20\%. Keputusan ini menunjukkan ekspresi antipengangkat berkemungkinan mengekalkan pH intrasel yang optimum dan kepekatan $\mathrm{Na}^{+}$atau $\mathrm{K}^{+}$, menyebabkan kemampuan sel untuk menerima kepekatan gliserol mentah yang tinggi.

Kata kunci: Bakteria asid asetik; biodiesel; dihidroksiaseton; gliserol kasar

\section{INTRODUCTION}

Biodiesel is an essential alternative biofuel derived from trans-esterification of animal and vegetable fats. The worldwide production and consumption of biodiesel has increased dramatically in recent years. As a result, crude glycerol, a major waste by-product of biodiesel production, is generated at approximately $10 \%(\mathrm{w} / \mathrm{w})$ in the biodiesel production process (Johnson \& Taconi 2007). Due to high impurity and low price of the excess crude glycerol, an expensive refining process is required (Almeida et al. 2012). Using crude glycerol directly obtained from biodiesel production as raw material without any additional treatment and purification to produce a valueadded compound would be advantageous. Numerous studies have demonstrated the microbial bioconversion of glycerol into useful products, such as 1,3-propanediol (Xiu et al. 2004), butanol (Taconi et al. 2009), succinic acid (Lee et al. 2001), polyhydroxyalkanoates (Koller et al.2005) and glyceric acid (Habe et al. 2009b). Similarly, microbial biotransformation of crude glycerol to 1,3-dihydroxyacetone (DHA) has been extensively studied and seems to be more effective than the chemical route (Liu et al. 2013). Dihydroxyacetone (DHA) is commonly used in cosmetic products (Brown 2001) and has been 
proposed for use in the pharmaceutical industry (Fesq et al. 2001). Among the known microbial DHA producers, Gluconobacter has been widely used in commercial production due to its high productivity and low formation of by-products (Adachi et al. 2003). The effectiveness of oxidative fermentation is well recognized; it is carried out by various dehydrogenase enzymes on the periplasmic membrane, which transfer electrons to the aerobic respiratory chain for bioenergy generation (Matsushita et al. 1994). Such reactions lead to a rapid oxidation of the alternative sugar acids and sugar alcohols and consequently to a high accumulation of the corresponding products in the culture medium. Among these membranebound dehydrogenase enzymes, PQQ-dependent glycerol dehydrogenase (PQQ-GLDH) shows versatility in substrate specificity and is responsible for the oxidation of glycerol to dihydroxyacetone (Matsushita et al. 2003). However, the DHA-production capability of G. oxydans was seen to be influenced by several parameters such as substrate inhibition, product inhibition and oxygen limitation (Ma et al. 2010). Recently, it was shown that a mutant G. oxydans M5 defective in the genes encoding alcohol dehydrogenase and aldehyde dehydrogenase exhibited higher DHA production than the wild type and yielded more DHA than could be obtained by the over-expression of glycerol dehydrogenase ( $\mathrm{Li}$ et al. 2010). In addition, using crude glycerol, which still contain impurities such as methanol, salts $\left(\mathrm{Na}^{+}\right.$or $\left.\mathrm{K}^{+}\right)$and fatty acids, was seen to inhibit growth and production yield (Chatzifragkou \& Papanikolaou 2012). One of the most challenging aspects of converting crude glycerol into value-added products, such DHA, is the need to find a highly effective microbial strain that can tolerate the impurities in crude glycerol. Several microorganisms have been investigated by random mutagenesis, for improvements in growth and production (Ma et al. 2010; Sato et al. 2014). This study attempts to screen and characterize a potential isolate of $\mathrm{AAB}$ for production of DHA from non-detoxified crude glycerol. In addition, the expression of a gene essential for $\mathrm{pH}$ homeostasis in G. frateurii NKC 115 will also be discussed.

\section{MATERIALS AND METHODS}

\section{BACTERIA AND GROWTH CONDITIONS}

YPGD medium consisting of $0.5 \%$ (w/v) glucose, glycerol, yeast extract and peptone (Soemphol et al. 2011) was used to prepare the seed culture. The cultivation was carried out on a rotary incubator shaker (Vision Scientific Co., Ltd. Korea) at $200 \mathrm{rpm}$ at $30^{\circ} \mathrm{C}$ for $24 \mathrm{~h}$. All newly isolated acetic acid bacteria $(\mathrm{AAB})$ were previously isolated from natural resources. Then, the reference $\mathrm{AAB}$ strains were maintained on YPGD medium supplemented with $1.5 \%$ agar and $0.5 \% \mathrm{CaCO}_{3}$. Cultures were kept active by periodic transfer to freshly prepared agar medium at $4^{\circ} \mathrm{C}$.

\section{CRUDE GLYCEROL}

Crude glycerol was provided by the Faculty of Engineering, Khon Kaen University, at a glycerol purity of approximately $50 \%(\mathrm{w} / \mathrm{w})$ (Teeka et al. 2012).

SCREENING EFFECTIVE ACETIC ACID BACTERIA FOR THE PRODUCTION OF 1,3- DIHYDROXYACETONE (DHA)

To examine the ability to produce DHA from crude glycerol, all isolates were cultured in YPGD medium for $18 \mathrm{~h}$ under the same conditions as described above. Five percent (v/v) of each cell culture was then transferred into $5 \mathrm{~mL}$ of YPGc, which was modified as described by Soemphol et al. (2011) and consisted of $10 \%$ crude glycerol (by weight), $0.5 \%$ yeast extract, $0.5 \%$ peptone and $0.1 \% \mathrm{MgSO}_{4}$. Finally, the $\mathrm{pH}$ of the medium was adjusted to 6.5 using conc. $\mathrm{H}_{2} \mathrm{SO}_{4}$ (99\%). The cells were then cultivated in culture medium at $30^{\circ} \mathrm{C}$ shaking at $200 \mathrm{rpm}$ and samples were collected at days 1, 3 and 5 of cultivation. The culture supernatant was obtained by centrifugation at $5,000 \times \mathrm{g}$ for $10 \mathrm{~min}$ and used for DHA measurement. The isolates that showed high production of DHA were selected for further investigation in YPGc with a final crude glycerol concentration of $10 \%$ $(\mathrm{w} / \mathrm{v})$.

\section{EFFECT OF CULTURE MEDIUM ON DHA PRODUCTION}

The effects of crude glycerol concentration, initial $\mathrm{pH}$ and nitrogen source of the YPGc medium were investigated to understand the effect of the medium on growth and DHA production. The initial crude glycerol concentration was adjusted to be 5, 10, 15 and $20 \%$ (w/v) in the YPGc medium, as shown above. The effect of the initial $\mathrm{pH}$ was investigated by preparing YPGc at a $10 \%(\mathrm{w} / \mathrm{v})$ crude glycerol concentration and adjusting the $\mathrm{pH}$ to $5.5,6.5$ and 7.5 using conc. $\mathrm{H}_{2} \mathrm{SO}_{4}$.

In addition, the effects of different nitrogen sources (yeast extract, peptone, $\left(\mathrm{NH}_{4}\right)_{2} \mathrm{SO}_{4}$ and urea) were investigated by replacing the nitrogen source in a common YPGc with either one or a mixture of the above nitrogen sources to a final of $1 \%(\mathrm{w} / \mathrm{v})$. Five percent of the preculture was cultivated on YPGD at $30^{\circ} \mathrm{C}$ for $18 \mathrm{~h}$ before being transferred to an Erlenmeyer flask containing $25 \mathrm{~mL}$ of the YPGc medium whose composition had been modified as described above. The growth and DHA production were monitored at days 1,3 , and 5 of cultivation.

\section{ANALYTICAL METHODS}

DHA concentration was measured using the 3,5-dinitrosalicylic acid (DNS) method as described by Black and Nair (2013). Briefly, the DNS solution was added to the sample at a $1: 1(\mathrm{v} / \mathrm{v})$ ratio and incubated at $100^{\circ} \mathrm{C}$ for $10 \mathrm{~min}$. The sample was then quickly placed into a water bath for $5 \mathrm{~min}$ prior to measurement of the absorbance at $550 \mathrm{~nm}$ using a spectrophotometer (Shimadzu UV1800, Japan). The DHA concentration was determined using a calibration curve of standard DHA solutions. 
Bacterial growth was measured by reading the optical density at $600 \mathrm{~nm}\left(\mathrm{OD}_{600 \mathrm{~nm}}\right)$ using a spectrophotometer (Shimadzu UV1800, Japan).

\section{IDENTIFICATION OF ACETIC ACID BACTERIA}

To identify the selected AAB isolates, the cells were cultured on YPGD medium at $30^{\circ} \mathrm{C}$ with rotary shaking at $200 \mathrm{rpm}$ until they reached the mid-log phase $(24 \mathrm{~h})$. The cells were then harvested by centrifugation and the chromosomal DNA was subsequently isolated as described by a previous report (Soemphol et al. 2008). Approximately $1.5 \mathrm{~kb}$ PCR products of 16S rRNA were obtained by amplification using a pair of universal primers, namely, 27F and $1525 \mathrm{R}$ and the PCR Go Taq Green Master Mix (Promega, Madison, WI). Multiple sequence alignments were performed using the CLUSTALW program (Thompson et al. 1994). The neighbour-joining phylogenetic tree was constructed using Mega version 6.0 with 1000 bootstrap replicates (Tamura et al. 2013).

\section{EXPRESSION OF NHAK2 INTO GLUCONOBACTER FRATEURII NKC115}

Plasmid pCMnhaK2, carrying nhaK2, the gene encoding for the $\mathrm{Na}^{+}\left(\mathrm{K}^{+}\right) / \mathrm{H}^{+}$antiporter of $A$. tropicalis $\mathrm{SKU} 1100$, was constructed (Soemphol et al. 2011) and transformed into competent cells of $G$. frateurii NKC115 by electroporation, according to a previous report (Soemphol et al. 2008). The transformant was selected for on YPGD agar medium containing $12.5 \mathrm{mg} / \mathrm{mL}$ of tetracycline.

\section{RESULTS AND DISCUSSION}

\section{SCREENING NEWLY ISOLATED AAB FOR EFFECTIVE DHA PRODUCTION FROM CRUDE GLYCEROL}

The AAB previously isolated from several sources were compared for their ability to produce DHA from crude glycerol. Two groups of 48 AAB isolates were used for preliminary examination. The first group (NKC) was identified within the genus Gluconobacter and it did not show over-oxidation but did show lower acetic acid resistance (data not shown). The latter group (FPB) had a strong ability to oxidize ethanol, which is consistent with acetate over-oxidation, and seemed to belong to the genus Acetobacter. For comparison, reference AAB strains, $G$. frateurii THD32 and A.tropicalis SKU1100, were used in this screen. As shown in Figure 1, the DHA accumulation after cultivation of these AAB on YPGc with $10 \%$ crude glycerol was observed in all AAB and clearly divided into 2 groups. The group similar to $G$. frateurii THD 32 produced a high amount of DHA at approximately 20-25 g/L. In contrast, the other group produced much less DHA and was similar to $A$. tropicalis SKU1100, with a DHA concentration below $5 \mathrm{~g} / \mathrm{L}$. Recently, the whole-genome analysis of A.pasteurianus has been reported and has showed that the genes encoding a membrane-bound glycerol dehydrogenase (GLDH), which is well characterized in Gluconobacter, do not exist in $A$. pasteurianus (Azuma et al. 2009). This could explain the lower accumulation of DHA in the isolates of the FPB strains, as it might be employed by another cytosolic enzyme, such

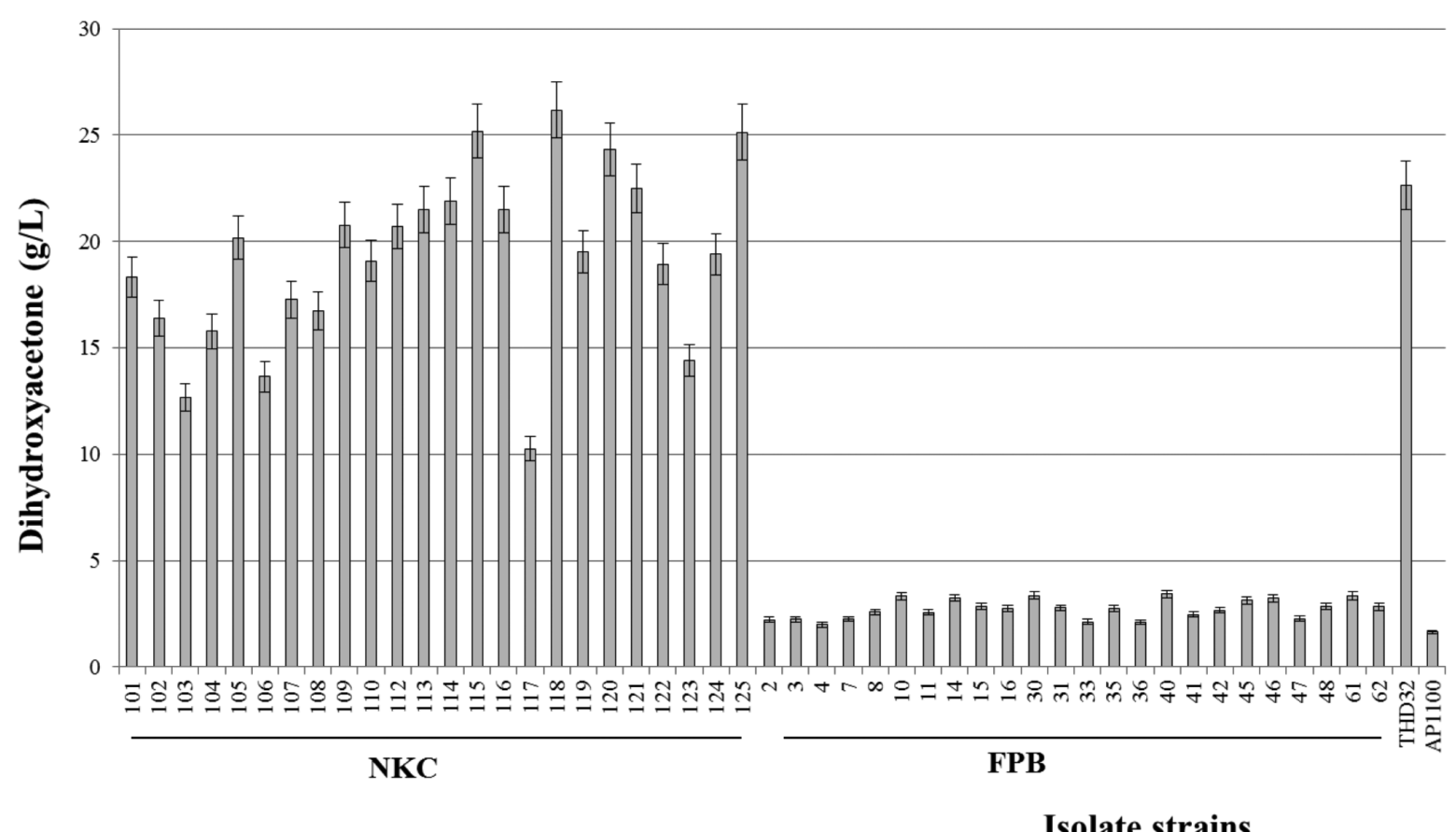

FIGURE 1. Dihydroxyacetone production from crude glycerol by newly isolated acetic acid bacteria. The culture supernatants of each isolate (NKC and FPB) after cultivation for 5 days in $5 \mathrm{~mL}$ of YPGc, were collected and measured for DHA concentration. SKU1100; A. tropicalis SKU1100, THD32; G. frateurii THD32 
as $\mathrm{NAD}^{+}$-dependent glycerol dehydrogenase (Soemphol et al. 2008).

\section{IDENTIFICATION OF NEWLY ISOLATED AAB}

Five isolates were selected for identification based on $16 \mathrm{~S}$ rRNA. A BLAST search showed that these 5 strains show high similarity to Gluconobacter with a similarity score greater than $99 \%$. A phylogenetic tree analysis using neighbour-joining demonstrated that isolates NKC115 and 120 are closely related to $G$. frateurii, while isolates
NKC118, NKC121 and NKC125 belong to the species $G$. japonicus (Figure 2).

The 5 isolates were then selected for further comparison of their growth and DHA production at $10 \%(\mathrm{w} / \mathrm{v})$ crude glycerol under shake flask conditions (Figure 3). These isolates had the highest DHA production, of approximately 25 $\mathrm{g} / \mathrm{L}$, after cultivation for 5 days and there was no significant difference between their yields. However, based on its growth ability, the isolate NKC115 was then selected as the $\mathrm{AAB}$ having the most potential for the purposes of this study and was carried forward for further study.

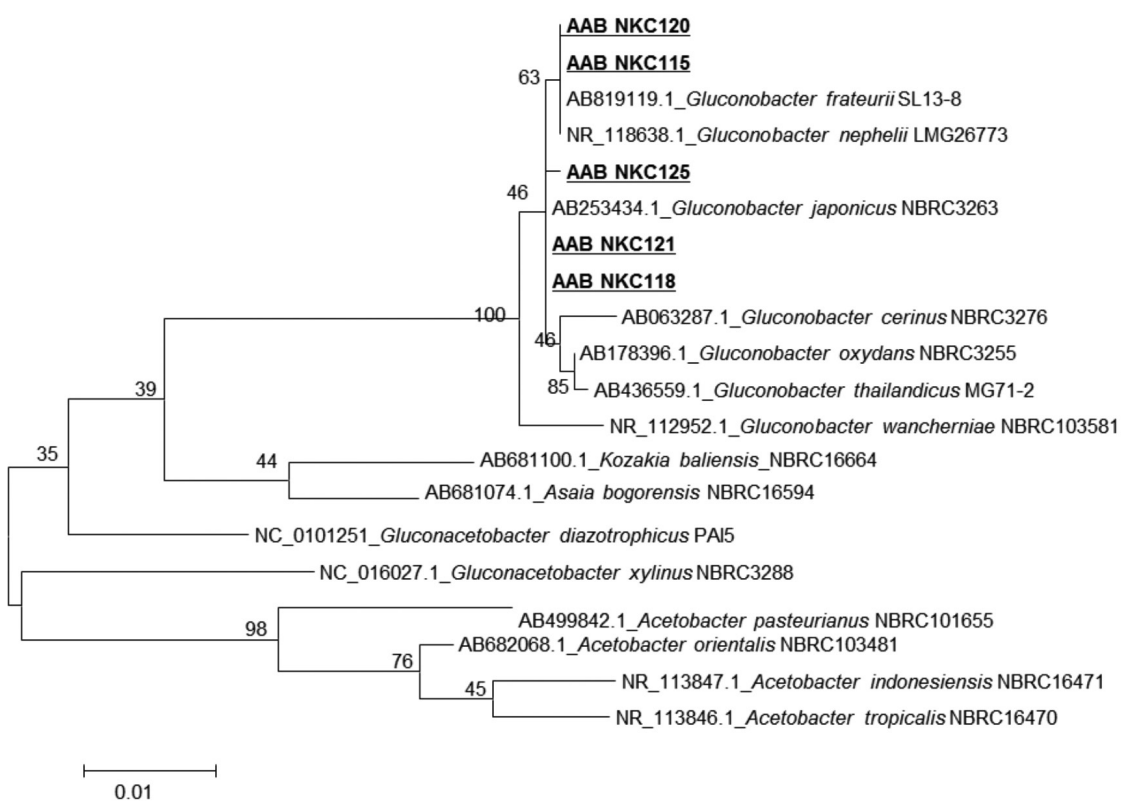

FIGURE 2. Phylogenetic analysis of the effective AAB, producing DHA from crude glycerol, compared with the other related AAB. The neighbour-joining phylogenetic tree was constructed with 1000 bootstrap replicates

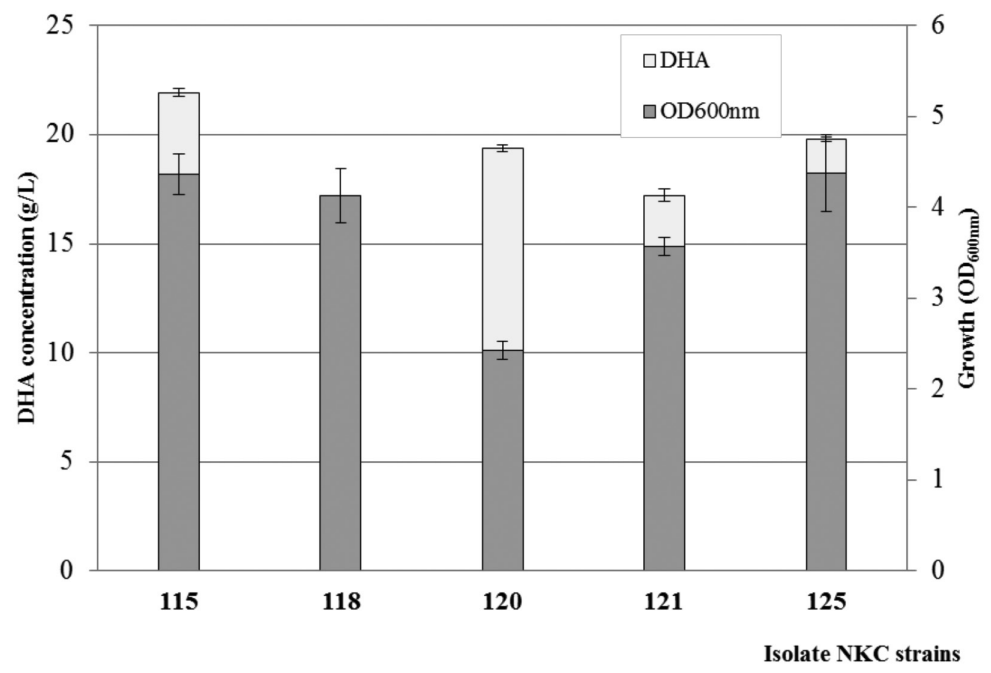

FIGURE 3. Comparison of DHA production (white bars) and growth ability (grey bars) of selected $\mathrm{AAB}$. The 5 selected isolates were cultured in shake flasks at $200 \mathrm{rpm}$. The culture supernatants were collected after 5 days of cultivation for measurement of DHA and growth (optical density, OD600 $\mathrm{nm}$ ) as described in the Materials and Methods section 


\section{EFFECT OF CRUDE GLYCEROL ON DHA PRODUCTION}

In the YPGc medium containing crude glycerol concentrations of $5,10,15$ or $20 \%$ (w/v), the production of DHA increased slightly when going from a glycerol concentration of $5 \%$ to $10 \%$, but seemed to be steady at concentrations above $10 \%$, with the highest DHA concentration achieved being $27.5 \mathrm{~g} / \mathrm{L}$ (Figure 4(a)). Similarly, the growth of this strain improved with an increase in crude glycerol concentration from $5 \%$ to $10 \%$. Growth was inhibited at concentrations above $15 \%$ (Figure 4(b)). It has been consistently reported that only $10.9 \mathrm{~g} / \mathrm{L}$ DHA could be produced from $200 \mathrm{~g} / \mathrm{L}$ of glycerol under shake flask conditions (Liu et al. 2013). The results suggested that higher concentrations of glycerol might suppress the ability of the cells to grow due to hyperosmotic stress (Ma et al. 2010) and may impair the cell division mechanism (Claret et al. 1992). There would also be feedback inhibition caused by the consequent accumulation of high amounts of DHA (Ma et al. 2010). In addition, the increased levels of several impurities that act as inhibitors could possibly affect microbial growth and production (Chatzifragkou \& Papanikolaou 2012). Immobilized cells of Gluconacetobacter xylinus have been employed to minimize the inhibition of substrate and product (Black \& Nair 2013).

\section{EFFECT OF THE INITIAL pH ON DHA PRODUCTION}

Growth and DHA production were examined in YPGc medium containing $10 \%(\mathrm{w} / \mathrm{v})$ crude glycerol with initial $\mathrm{pH}$ values adjusted to $5.5,6.5$ or 7.5 (Figure 5). The results showed that the initial $\mathrm{pH}$ values tested did not affect the growth or DHA production, with the highest DHA concentration $(27.82 \mathrm{~g} / \mathrm{L})$ being achieved by a culture with an initial $\mathrm{pH}$ of 6.5 . However, the optimum $\mathrm{pH}$ for DHA production tended to be below neutral $\mathrm{pH}$.
Upon cultivation, the $\mathrm{pH}$ values of the culture media from these three conditions were seen to gradually decrease and the $\mathrm{pH}$ value was seen to stabilize at approximately 5.0 (data not shown). This may explain the formation of other sugar acids, for instance, DL-glyceric acid, which is another by-product of glycerol oxidation by acetic acid bacteria (Habe et al. 2009a). It has been reported that glycerol dehydrogenase (GLDH) activity has an optimal $\mathrm{pH}$ of approximately 5.0 and requires divalent metal ions such as $\mathrm{Ca}^{2+}$ or $\mathrm{Mg}^{2+}$ (Adachi et al. 2001; Ameyama et al. 1985). Therefore, the optimal $\mathrm{pH}$ for cell growth and DHA production is an acidic $\mathrm{pH}$.

\section{EFFECT OF NITROGEN SOURCE ON DHA PRODUCTION}

The effect of various organic and inorganic nitrogen sources were compared in shake flasks, including yeast extract mixed with peptone (each $5 \mathrm{~g} / \mathrm{L}$ ), yeast extract (10 $\mathrm{g} / \mathrm{L})$, peptone $(10 \mathrm{~g} / \mathrm{L}),\left(\mathrm{NH}_{4}\right)_{2} \mathrm{SO}_{4}(10 \mathrm{~g} / \mathrm{L})$ and urea $(10$ $\mathrm{g} / \mathrm{L})$. As shown in Figure 6, poor cell growth and low DHA production were observed with all the inorganic nitrogen sources tested, while G. frateurii NKC115 achieved the highest DHA concentration $(34.70 \mathrm{~g} / \mathrm{L})$ by using peptone (P). It has been reported that yeast extract and peptone are the optimal nitrogen sources for DHA production by G. oxydans ZJB09112 and that there was no remarkable difference in DHA production between the two ( $\mathrm{Hu}$ et al. 2010). However, among the nitrogen sources tested in this study, peptone seemed to be the most favourable nitrogen source. Since yeast extract and peptone are expensive, it is desirable to find a cheaper complex nitrogen source to produce DHA. Liu et al. (2013) reported that the use of corn steep liquor (CSL) instead of two expensive nitrogen sources resulted in comparable amounts of DHA production by $G$. frateurii CGMCC5397. (a)

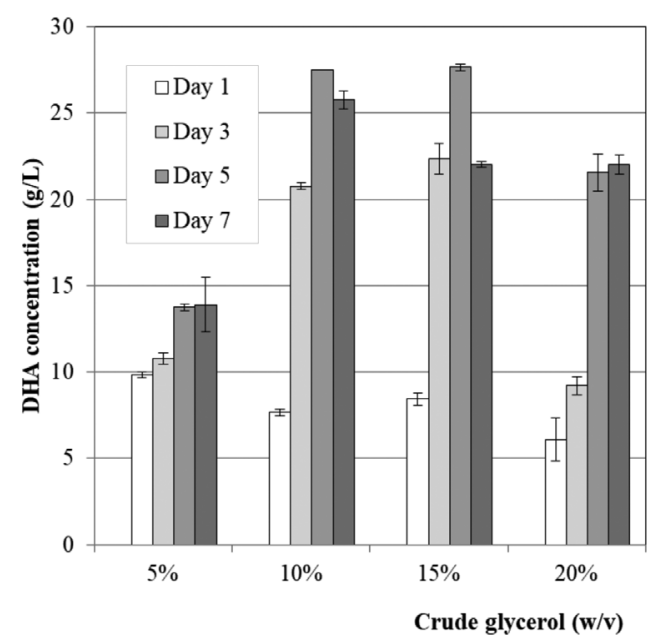

(b)

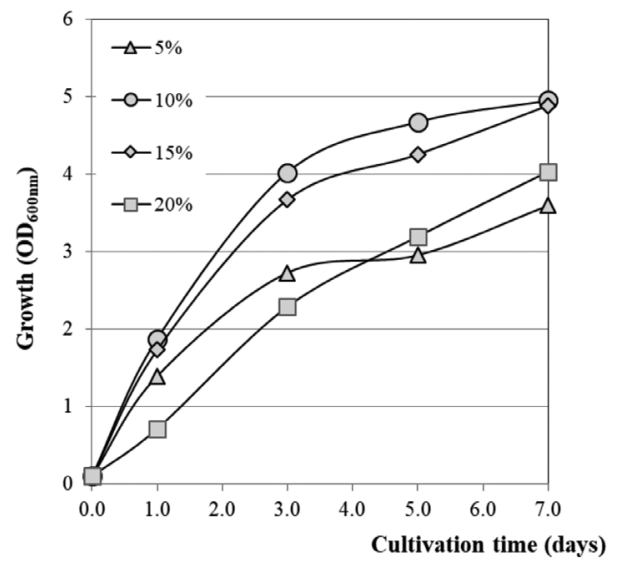

FIGURE 4. Effect of crude glycerol concentration on DHA production (a) and growth of G. frateurii NKC115 (b). The preculture of $G$. frateurii NKC115 was transferred into a $250 \mathrm{~mL}$ Erlenmeyer flask containing $25 \mathrm{~mL}$ of YPGc with different concentrations of crude glycerol, as indicated. DHA concentration and growth were monitored at days 1,3,5, and 7 of cultivation 
(a)

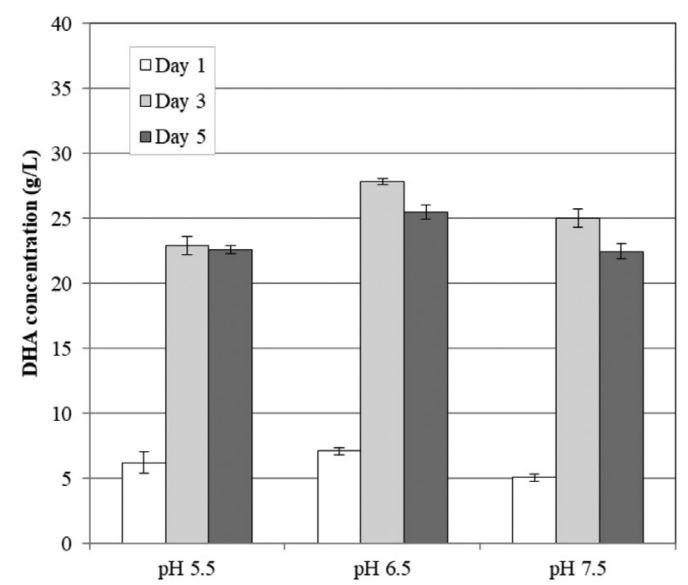

(b)

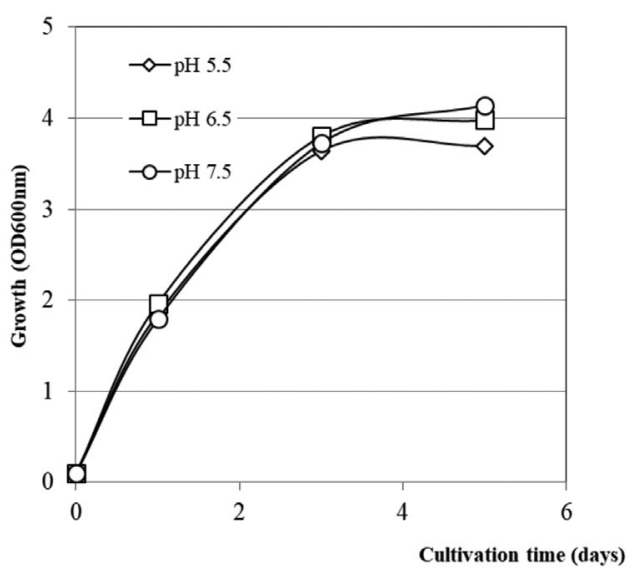

FIGURE 5. Effect of initial pH on DHA production (a) and growth of G. frateurii NKC115 (b). The preculture of G. frateurii NKC115 was transferred into a $250 \mathrm{~mL}$ Erlenmeyer flask containing $25 \mathrm{~mL}$ of YPGc at different $\mathrm{pH}$ values, as indicated. DHA concentration and growth were monitored at days 1, 3 and 5 of cultivation

(a)

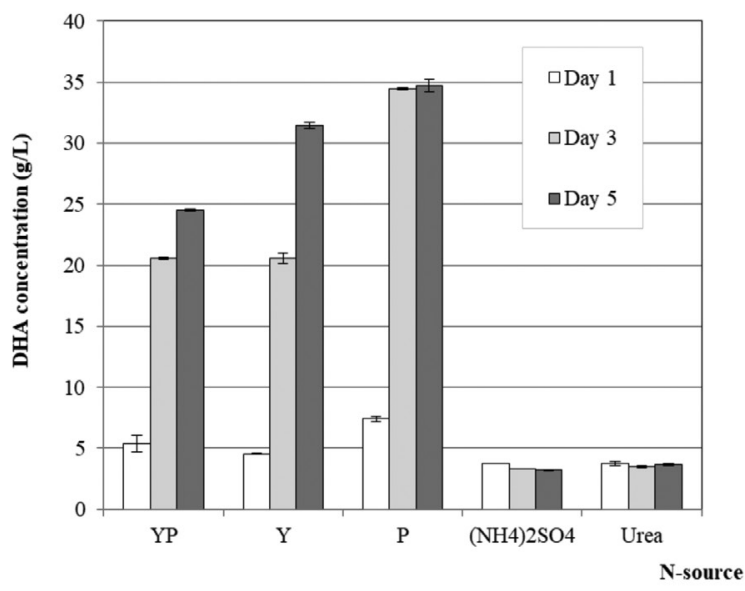

(b)

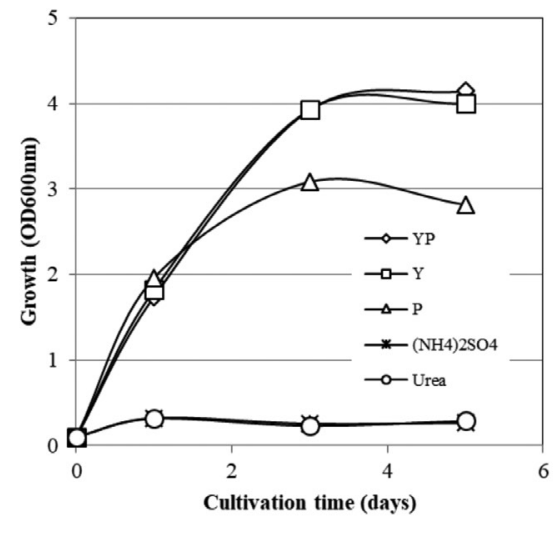

FIGURE 6. Effect of different nitrogen sources on DHA production (a) and growth of G. frateurii NKC115 (b). The preculture of $G$. frateurii NKC115 was transferred into a $250 \mathrm{~mL}$ Erlenmeyer flask containing $25 \mathrm{~mL}$ of YPGc at different $\mathrm{pH}$ values, as indicated. DHA concentration and growth were monitored at days 1,3 , and 5 of cultivation

\section{IMPROVEMENT OF GROWTH AND DHA PRODUCTION OF G. FRATEURII NKC115}

Since an increase in crude glycerol suppresses the growth of $G$. frateurii NKC115, it is possible that it is not only glycerol or DHA that have this effect; several impurities in crude glycerol have been seen to highly inhibit either cellular growth or production (Chatzifragkou \& Papanikolaou 2012). Potassium or sodium compounds are used as the catalyst in the transesterification of crude glycerol at a strongly alkaline $\mathrm{pH}$ of approximately 12.0 and might have an effect on the bacterial growth. According to our previous report, we found that the gene $n h a \mathrm{~K} 2$, encoding the $\mathrm{Na}^{+}\left(\mathrm{K}^{+}\right) / \mathrm{H}^{+}$antiporter of A. tropicalis SKU1100, plays an important role in the maintenance of intracellular $\mathrm{pH}$ and $\mathrm{K}^{+}$homeostasis (Soemphol et al.2015). Moreover, expression of this gene was seen to successfully improve the growth of other AAB in media supplemented with potassium, in addition to growth at high temperature. Therefore, the shuttle vector pCMnhaK2 containing this gene was then transformed into G. frateurii NKC115, resulting in the strain $G$. frateurii NKC115 (pCMnhaK2), while the empty vector pCM62 was also transformed and showed no effect on growth compared to the wild-type strain (data not shown). As seen in Figure 7, expression of this gene clearly improved the growth of $G$.frateurii NKC115 even though the growth gradually decreased with increasing concentrations of crude glycerol. Furthermore, DHA production improved when crude glycerol was used at $20 \%$ and was higher than that at $10 \%$ with a maximum concentration of 37.25 $\mathrm{g} / \mathrm{L}$. This result suggested that the expression of a $\mathrm{Na}^{+} / \mathrm{H}^{+}$ antiporter might maintain an optimal intracellular $\mathrm{pH}$ and 
(a)

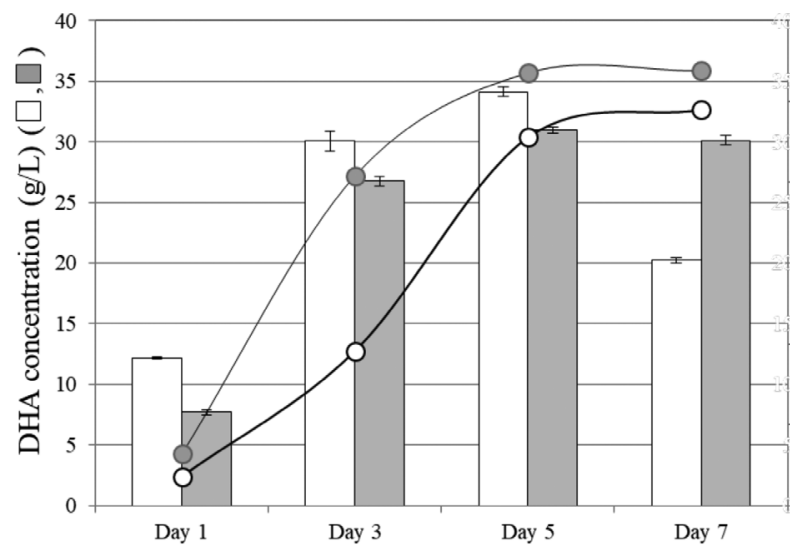

(b)

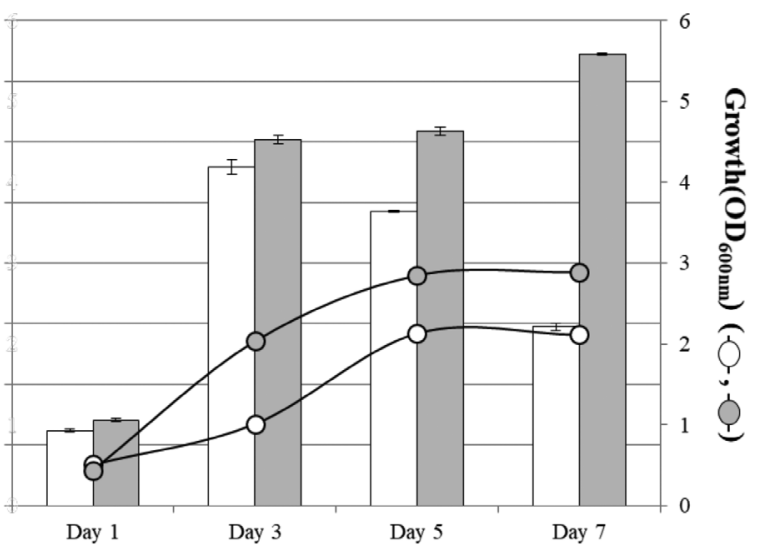

FIGURE 7. Expression of the $\mathrm{Na}^{+}\left(\mathrm{K}^{+}\right) / \mathrm{H}^{+}$antiporter of A. tropicalis SKU1100 in G. frateurii $\mathrm{NKC115}$. Growth (line graph) and DHA production (bar graph) were examined by comparing expression of wild-type G. frateurii NKC115 (open circle and white bar) with the transformant $G$. frateurii NKC115 (pCMnhaK2) (close circle and grey bar). Both strains were cultured in YPGc containing $10 \%$ (a) and $20 \%$ (b) of crude glycerol

concentration of $\mathrm{Na}^{+}$or $\mathrm{K}^{+}$resulting in the cells' ability to tolerate higher concentrations of crude glycerol. The chemical mutagenesis of $G$. oxydans by NTG treatment resulted in the cells' ability to tolerate methanol and led to an improvement of growth and DHA production in the presence of methanol (Sato et al. 2014). Low-power laser (He-Ne) irradiation is currently used to construct the mutant G. oxydans GM51, which is employed for lower substrate inhibition and the improvement of DHA productivity (Ma et al. 2010).

\section{CONCLUSION}

In conclusion, waste glycerol represents a carbon source that is widely available at a relatively low cost and is potentially suitable for many applications. This study demonstrated that NKC115, a new isolate identified as $G$. frateurii, is able to utilize non-detoxified crude glycerol to accumulate a considerable amount of DHA. In this study, the highest amount DHA production was $37.25 \mathrm{~g} / \mathrm{L}$ from $20 \%(\mathrm{w} / \mathrm{v})$ crude glycerol by the over-expressed strain, which could also tolerate a higher concentration of crude glycerol than the wild type. However, an increase in the concentration of crude glycerol may result in growth inhibition and decreased DHA production. Obtained from different biodiesel plants, the glycerol by-products might have variable compositions of impurities, making it difficult to control the production of DHA. The use of the most robust microbial strain might fulfill the industrial demands of DHA production from crude glycerol and decrease the production costs. There is potential for efficient DHA production; however, the fermentation process and molecular methods should be optimized in order to improve the efficacy of G. frateurii NKC115 for DHA production from crude glycerol.

\section{ACKNOWLEDGEMENTS}

This work was supported by funding from Nong Khai Campus, Khon Kaen University. The authors wish to thank Prof. Dr. Kazunobu Matsushita for kindly providing the plasmid pCMnhaK2. We thank Mr. Thanin Kaenthani and Mr. Apisit Nongpho for technical support.

\section{REFERENCES}

Adachi, O., Fujii, Y., Ghaly, M.F., Toyama, H., Shinagawa, E. \& Matsushita, K. 2001. Membrane-bound quinoprotein D-arabitol dehydrogenase of Gluconobacter suboxydans IF0 3257: A versatile enzyme for the oxidative fermentation of various ketoses. Bioscience Biotechnology Biochemistry 65: 2755-2762.

Almeida, J.R.M., Fávaro, L.C.L. \& Quirino, B.F. 2012. Biodiesel biorefinery: Opportunities and challenges for microbial production of fuels and chemicals from glycerol waste. Biotechnology for Biofuels 48: 1-16.

Ameyama, M., Shinagawa, E., Matsushita, K. \& Adachi, O. 1985. Solubilization, purification and properties of membranebound glycerol dehydrogenase from Gluconobacter industrius. Agricultural and Biological Chemistry 49: 1001-1010.

Azuma, Y., Hosoyama, A., Matsutani, M., Furuya, N., Horikawa, H., Harada, T., Hirakawa, H., Kuhara, S., Matsushita, K., Fujita, N. \& Shirai, M. 2009. Whole-genome analyses reveal genetic instability of Acetobacter pasteurianus. Nucleic Acids Research 37: 5768-5783.

Black, C.S. \& Nair, G.R. 2013. Bioconversion of glycerol to dihydroxyacetone by immobilized Gluconacetobacter xylinus cells. International Journal of Chemical Engineering and Applications 4: 310-316.

Brown, D.A. 2001. Skin pigmentation enhancers. Journal of Photochemistry Photobiology B 63: 148-161.

Chatzifragkou,A. \& Papanikolaou, S. 2012. Effect of impurities in biodiesel-deri ved waste glycerol on the performance and feasibility of biotechno logical processes. Applied Microbiology and Biotechnology 95: 13-27. 
Claret, C., Bories, A. \& Soucaille, P. 1992. Glycerol inhibition of growth and dihydroxyacetone production by Gluconobacter oxydans. Current Microbiology 25: 149-155.

Fesq, H., Brockow, K., Strom, K., Mempel, M., Ring, J. \& Abeck, D. 2001. Dihydroxyacetone in a new formulation-a powerful therapeutic option in vitiligo. Dermatology 203: 241-243.

Habe, H., Fukuoka, T., Kitamoto, D. \& Sakaki, K. 2009a. Biotechnological production of D-glyceric acid and its application. Applied Microbiology and Biotechnology 84: 445-452.

Habe, H., Shimada, Y., Fukuoka, T., Kitamoto, D., Itagaki, M., Watanabe, K., Yanagishita, H. \& Sakaki, K. 2009b. Production of glyceric acid by Gluconobacter sp. NBRC3259 using raw glycerol. Bioscience Biotechnology and Biochemistry 73: 1799-1805.

Hu, Z.C., Liu, Z.Q., Zheng, Y.G. \& Shen, Y.C. 2010. Production of 1,3-dihydroxyacetone from glycerol by Gluconobacter oxydans ZJB09112. Journal of Microbiology and Biotechnology 20: 340-345.

Johnson, D.T. \& Taconi, K.A. 2007. The glycerin glut: Options for the value-added conversion of crude glycerol resulting from biodiesel production. Environmental Progress 26: 338-348.

Koller, M., Bona, R., Braunegg, G., Hermann, C., Horvat, P., Kroutil, M., Martinz, J., Neto, J., Pereira, L. \& Varila, P. 2005. Production of polyhydroxyalkanoates from agricultural waste and surplus materials. Biomacromolecules 6: 565-561.

Lee, P.C., Lee, W.G., Lee, S.Y. \& Chang, H.N. 2001. Succinic acid production with reduced by-product formation in the fermentation of Anaerobiospirillum succiniciproducens using glycerol as a carbon. Biotechnology and Bioengineering 78: 41-48.

Li, M.H., Wu, J., Liu, X., Lin, J.P., Wei, D.Z. \& Chen, H. 2010. Enhanced production of dihydroxyacetone from glycerol by overexpression of glycerol dehydrogenase in an alcohol dehydrogenase-deficient mutant of Gluconobacter oxydans. Bioresource Technology 101: 8294-8299.

Liu, Y.P., Sun, Y., Tan, C., Li, H., Zheng, X.J., Jin, K.Q. \& Wang, G. 2013. Efficient production of dihydroxyacetone from biodiesel-derived crude glycerol by newly isolated Gluconobacter frateurii. Bioresource Technology 142: 384-389.

Ma, L., Lu, W., Xia, Z. \& Wen, J. 2010. Enhancement of dihydroxyacetone production by a mutant of Gluconobacter oxydans. Biosysthesis and Engineering Journal 49: 61-67.

Matsushita, K., Toyama, H. \& Adachi, O. 1994. Respiratory chains and bioenergetics of acetic acid bacteria. Advanced Microbial Physiology 36: 247-301.

Matsushita, K., Fujii, Y., Ano, Y., Toyama, H., Shinjoh, M., Tomiyama, N., Miyazaki, T., Sugisawa, T., Hoshino, T. \& Adachi, O. 2003.5-Keto-D-gluconate production is catalyzed by a quinoprotein glycerol dehydrogenase, major polyol dehydrogenase, in Gluconobacter species. Applied and Environmental Microbiology 69: 1959-1966.

Sato, S., Kitamoto, D. \& Habe, H. 2014. Chemical mutagenesis of Gluconobacter frateurii to construct methanol-resistant mutants showing glyceric acid production from methanolcontaining glycerol. Journal of Boscience and Bioengineering 117: 197-199.

Soemphol, W., Adachi, O., Matsushita, K. \& Toyama, H. 2008. Distinct physiological roles of two membrane-bound dehydrogenases responsible for D-sorbitol oxidation in Gluconobacter frateurii. Bioscience Biotechnology and Biochemistry 72: 842-850.
Soemphol, W., Tatsuno, M., Okada, T., Matsutani, M., Kataoka, N., Yakushia, T. \& Matsushita, K. 2015. A novel $\mathrm{Na}^{+}\left(\mathrm{K}^{+}\right) /$ $\mathrm{H}^{+}$antiporter plays an important role in the growth of Acetobacter tropicalis SKU1100 at high temperatures via regulation of cation and $\mathrm{pH}$ homeostasis. Journal of Biotechnology 211: 46-55.

Soemphol, W., Deeraksa, A., Matsutani, M., Yakushi, T., Toyama, H., Adachi, A., Yamada, M. \& Matsushita, K. 2011. Global analysis of the genes involved in the thermotolerance mechanism of thermotolerant Acetobacter tropicalis SKU1100. Bioscience Biotechnology and Biochemistry 75: 1921-1928.

Taconi, K.A., Venkataramanan, K.P. \& Johnson, D.T. 2009. Growth and solvent production by Clostridium pasteurianum ATCC(R)6013(TM) utilizing biodiesel-derived crude glycerol as the sole carbon source. Environmental Progress \& Sustainable Energy 28: 100-110.

Tamura, K., Stecher, G., Peterson, D., Filipski, A. \& Kumar, S. 2013. MEGA6: Molecular evolutionary genetics analysis. Version 6.0. Molecular Biology and Evolution 30: 2725-2729.

Teeka, J., Imai, T., Reungsang, A., Cheng, X., Yuliani, E., Thiantanankul, J., Poomipuk, N., Yamaguchi, J., Jeenanong, A., Higuchi, T., Yamamoto, K. \& Sekine, M. 2012. Characterization of polyhydroxyalkanoates (PHAs) biosynthesis by isolated Novosphingobium sp. THA_AIK7 using crude glycerol. Journal of Industrial Microbiology and Biotechnology 39: 749-758.

Thompson, J.D., Higgins, D.G. \& Gibson, T.J. 1994. CLUSTAL $\mathrm{W}$ : Improving the sensitivity of progressive multiple sequence alignment through sequence weighting, position-specific gap penalties and weight matrix choice. Nucleic Acids Research 22: 4673-4680

Xiu, Z.L., Song, B.H., Wang, Z.T., Sun, L.H., Feng, E.M. \& Zeng, A.P. 2014. Optimization of dissimilation of glycerol to 1,3-propanediol by Klebsiella pneumoniae in one- and two-stage anaerobic cultures. Biochemical Engineering Journal 19: 189-197.

Varavut Tanamool

Chemistry Program, Faculty of Science and Technology

Nakhon Ratchasima Rajabhat University

Nakhon Ratchasima, 30000

Thailand

Piyorot Hongsachart \& Wichai Soemphol* Faculty of Applied Sciences and Engineering

Khon Kaen University

Nong Khai Campus, Nong Khai, 43000

Thailand

*Corresponding author; email: wichso@kku.ac.th

Received: 7 October 2015

Accepted: 9 October 2017 